\title{
Does Bribery Sand the Wheels? New Evidence from Small and Medium Firms in Vietnam*
}

\author{
Toan Ngoc NGUYEN**
}

Received: February 6, 2020

Revised: February 24, 2020

Accepted: March 1, 2020.

\begin{abstract}
This research aims to revisit the hypothesis that bribery hurts firm performance in the context of a perceptibly corrupt country. Specifically, we use micro-data from Vietnamese small and medium firm surveys in 2013 and 2015 to examine whether bribery impedes firm revenue growth and labor productivity growth. An issue arising in this type of research is the potential endogeneity between firm bribing behaviors and firm performance. To go around the issue, we follow the literature to instrument bribery variable with the average probability of bribery in other provinces. We further employ the Analysis of Variance technique (ANOVA) to unveil if the effect of bribery is dependent on bribing purposes. The regression results show that firm performance is significantly influenced by firm size, firm age and firm bribing behavior. Larger firms are more likely to grow faster while firm performance tends to be negatively related to firm age. Particularly, we find that bribery significantly impedes firm revenue growth and labor productivity growth. The analysis of variance shows that the effect of bribery on firm performance may vary across bribing purposes. Our findings, therefore, support the sand-the-wheels hypothesis that bribery hurts firm performance even in a highly corrupt business environment.
\end{abstract}

Keywords : Bribery, Firm Performance, Sand the Wheels, Vietnam

JEL Classification Code: D22, D73, O17

\section{Introduction}

Does bribery sand or grease the wheels? The relationship between bribery and firm performance has been intensively analyzed in the literature but the final consensus is yet to attain. One strand of studies stresses that bribery has adverse influence on firm performance, which is known as "sand the wheels" view (Mauro, 1995; Wu,

\footnotetext{
*The author would like to thank the World Institute for Development Economic Research, United Nations University (UNU-WIDER) for making available the data of CIEM, ILSSA, UCPH, and UNUWIDER (2013 and 2015) Vietnam SME Surveys, which are used in this research.

${ }^{* *}$ First Author and Corresponding Author. Lecturer, Institute of Economics, Ho Chi Minh Academy of Politics, Vietnam [Postal Address: 135 Nguyen Phong Sac Street, Cau Giay District, Hanoi 10065, Vietnam] Tel: +84 965-588-408,

Email: toankyoto@gmail.com

(c) Copyright: The Author(s)

This is an Open Access article distributed under the terms of the Creative Commons Attribution Non-Commercial License (http://Creativecommons.org/licenses/by-nc/4.0/) which permits unrestricted noncommercial use, distribution, and reproduction in any medium, provided the original work is properly cited.
}

2009). Also, ACCA (2013) shows that 70 percent of small and medium enterprises in transition economies perceive corruption as an impediment to their business. It is argued that small and medium enterprises are susceptible to corruption and that they often use higher percentages of their revenue to pay bribes, compared to large companies (Bai, Jayachandra, Malesky, \& Oken, 2019; UNIDO \& UNODC, 2007). Another strand of studies follows the reverse view that, in corrupted business environments, bribery does "grease the wheels" to get things done and thus boost firm performance (Gaviria, 2002; Gundlach \& Paldam, 2009; Hellman \& Schankerman, 2000; Treisman, 2000). The third view states that whether bribery sands or greases the wheels may depend on a number of factors, such as firm characteristics, the types of bribery and the contextual settings where firms operate (Zhou \& Peng, 2012).

This paper reexamines the hypothesis that bribery impedes firm performance with the case of small and medium firms in Vietnam using micro-data from small and medium enterprise surveys in 2013 and 2015. Vietnam has experienced rapid economic growth in the past decades, 
thanks to the inflow of foreign direct investment and the expansion of the private sector, in which most firms are of small and medium size. However, these firms might be susceptible to bribery in the context of perceivably widespread corruption. According to Campbell and Thomas (2019), 56 percent of respondents in Vietnam thought that corruption had increased, and 60 percent believed that the government had been ineffective in fighting corruption. Bribery rate is particularly high in Vietnam as 65 percent of respondents had to pay a bribe when accessing public services. This environment of relatively high corruption is ideal for retesting the competing hypotheses of sanding or greasing the wheels. We focus on small and medium firms since they are more likely to be victims of bribery (Hellman \& Schankerman, 2000; Zhou \& Peng, 2012). Small and medium firms might be unable to resist corrupt officials and they lack internal disciplines to deal with corruption (Arvis \& Berenbeim, 2003; Svensson, 2003). Yin and Zhang (2019) proved that the larger the firm, the more likely has corporate anti-corruption practice disclosure. Two alternative measures of firm performance, revenue growth and labor productivity growth, are used as dependent variables. The key independent variable is bribery dummy, which is one if a firm engages in bribery and is zero otherwise. Variables of firm characteristics and owner characteristics are used as control variables. We also employ the Analysis of Variance (ANOVA) to explore whether the effects of bribery on firm performance vary among different purposes of bribery, as stated in the third view.

One issue with studies on this topic is that firm performance may also reversely influence bribery behaviors. For example, Bai et al., (2019) found that firm growth reduces bribery as a share of revenues. Wu (2009) showed that firm size, growth rate, among others, are determinants of bribery in Asian firms. Clarke and Xu (2004) confirmed that firms are more likely to pay bribes when they are more profitable, or they are new firms. To go around the potential endogeneity between firm performance and firm bribery behavior, we instrument firm bribery with an average level of bribery incidents of all provinces other than the province where the firm is located. We believe that the firm's probability to bribe is correlated with the average probability to bribe in other provinces, given the same legal and political systems across provinces. Firm performance is also less likely to be correlated with the bribery level in other provinces.

The remainder of the paper is structured as follows. Section 2 briefly reviews the literature of bribery and firm performance relationship. Section 3 describes the analytical methods and the data used in this paper. Section 4 presents estimation results and discuss findings. The final section is, as usual, conclusion.

\section{Literature Review}

The relationship between bribery and firm performance has been analyzed intensively in the literature with inconclusive results. One strand in the literature states that bribery hurts firm performance. It is argued that bribery raises firms' costs (Kaufmann \& Wei, 1999) and discourages firms' investment (Romer, 1994). Firms may choose to remain small to avoid bureaucratic procedures and corruption by public officials and thus deliberately reduce their growth (Gauthier \& Goyette, 2014). Another explanation stresses that the existence of bribery undermines firms' investment and innovations (Asiedu \& Freeman, 2009; Méon \& Sekkat, 2005; O'Toole \& Tarp, 2014). Firms tend to switch to ren-seeking behaviors instead of focusing on productivity improvement (Dal Bó \& Rossi, 2007; Murphy, Shleifer, \& Vishny, 1991). This line of view is often mentioned as the "sand the wheels" hypothesis. Several empirical studies have found evidence supporting this hypothesis, showing that bribery negatively influences firm performance (De Rosa, Nishaal, \& Holger, 2015; Fisman \& Svensson, 2007; Gaviria, 2002). Dutta and Sobel (2016) proved, by using a large dataset from World Bank, that even in the bad business climate, corruption empirically hurts entrepreneurship.

Another line of the literature suggests that bribery may boosts performance or "grease the wheels" of commerce. It is argued that firms use bribery to get things done faster in a bad business environment, where corrupt public officials hinder firm activities. Bribery is considered a way to overcome business barriers. Some studies using data from countries with high corruption rates showed that bribery improves firm performance (Hellman, Jones, Kaufman, \& Shankerman, 2000; Radaev, 2004). Dreher and Gassebner (2013) used data from 43 countries to prove that corruption boost firm performance in countries where firms face a great number of procedures. De Rosa et al. (2015) investigated 11,000 firms in 28 countries using data from Business Environment and Enterprise Performance Survey in 2009 and found that in countries with the corruption perception index greater than 2.99 , bribery positively influences firm productivity. Mendoza, Lim, and Lopez (2015) used data of 2000 micro, small and medium enterprises in over thirty cities in the Philippines. They showed that bribery has a positive impact on the performance of some firms, notably those that are influenced by red tape. It is also argued that a good relationship with public officials might help increase firm performance (Fisman, 2001; Park \& Lue, 2001; Peng \& Luo, 2000).

The third strand of studies is somewhat eclectic. It stresses that whether bribery impedes, or boosts growth depends on several factors, such as firm characteristics, 
types of bribery, or the environment in which firms operate. For example, Zhou and Peng (2012) explored a large, crosscountry sample of 2,686 firms and found that bribery hurts the growth of small and medium firms but not large firms. Small firms may be more vulnerable to bribery since their bargaining power is weaker when facing corrupt public officials (Young, Ahlstrom, Bruton, \& Rubanik, 2011). Furthermore, as small firms are constrained by limited resources, they may be more susceptible to shocks than larger firms. On the other hand, larger firms, with better resources and connections with public officials, are more likely to strategically take bribery activities for their benefits (Hellman \& Schankerman, 2000). Thus, bribery may have different effects on firms of different sizes. Nurtegin and Jakee (2019) also revisited the hypotheses that corruption greases or sands the wheels of commerce using micro-data. They found that the effects of corruption vary by type of corruption. Most types of corruption impede firm growth while others may facilitate it. Hanoteau and Vial (2014) pointed out that the grease-the-wheels and sand-thewheels effects may co-exist among Indonesian firms and the effect of corruption depends on firms' drivers of productivity.

\section{Research Methods and Materials}

In this research, we revisit the "sand the wheels" hypothesis that bribery hurts firm performance with microdata of small and medium firms from Vietnam. As Vietnam is a country with high perception of corruption (Campbell \& Thomas, 2019), we expect to see evidence to reject the hypothesis in favor of the grease-the-wheels hypothesis. Specifically, we attempt to answer the following questions:

Question 1: Does bribery generally impede small and medium firm performance?

Question 2: Does the effect of bribery on small and medium firm performance vary across bribery purposes?

To find the answer the first question, we regress firm performance indicators on bribery dummy and several other variables. Two measures of firm performance are considered: revenue growth and labor productivity growth. These indicators of firm performance have been used extensively in the literature (for example, in Fisman \& Svensson, 2007; Mendoza et al, 2015; Vial \& Hanoteau, 2010; Zhou \& Peng, 2012). Our expectation is that bribery may influence these indicators of performance somewhat differently. Revenue growth is an apparent goal of firms, indicating whether firms have done well in their business. However, annual revenue growth may not reflect the intrinsic improvement of firms and may just be a short-term phenomenon. On the contrary, labor productivity growth may reflect changes in employment structure and technological progress, which are important to firms' future development. It may happen that bribery is good for firms in the short term and bad for firms in the longer term. We use data from Vietnamese small and medium enterprise (SMEs) surveys, which were conducted every two years from 2011 to 2015. Data were collected in 9 provinces of Vietnam, including Hanoi, Hai Phong, Hochiminh City, Phu Tho, Nghe An, Quang Nam, Khanh Hoa, Lam Dong, and Long An, based on face-to-face interviews with firm owners or managers. These are provinces which have a relatively large number of small and medium firms in Vietnam. Survey data in 2015 are the main source for our analysis. However, we also use data from the survey in 2013 to compute labor productivity growth.

The first regression uses revenue growth as dependent variable. Revenue growth is measured as the first difference of the logarithms of firm revenues in 2014 and 2013, which are reported in the 2015 survey. After discarding missing values and outliers, we have 2,637 observations. Independent variables are comprised of the bribery dummy variable, variables of firm characteristic and business environment characteristics. In small and medium firms, owner/manager characteristics might influence performance. For example, Essel, Adams, and Amankwah (2019) investigated 200 small firms in Ghana and found that demographic factors of firm operators such as gender and education can affect firm performance. Thus, some characteristics of owners/managers are included as well. Detailed explanation of the variables is given in Table 1.

Table 1: List of dependent and independent variables

\begin{tabular}{|c|c|}
\hline Variable & Description \\
\hline \multicolumn{2}{|r|}{ Dependent variable } \\
\hline Revenue growth & $\begin{array}{c}\text { Difference in logarithms of revenue in } 2014 \\
\text { and revenue in } 2013\end{array}$ \\
\hline $\begin{array}{l}\text { Labor productivity } \\
\text { growth }\end{array}$ & $\begin{array}{l}\text { Difference in logarithms of revenue per full- } \\
\text { time labor in } 2014 \text { and in } 2012\end{array}$ \\
\hline \multicolumn{2}{|r|}{ Firm characteristics } \\
\hline Bribery & $\begin{array}{c}\text { Dummy variable which is one if a firm pays } \\
\text { bribe. }\end{array}$ \\
\hline Firm size & Total assets of firm in logarithm \\
\hline Firm age & $\begin{array}{c}\text { Logarithms of the number of years since firm } \\
\text { established }\end{array}$ \\
\hline Household firm & $\begin{array}{l}\text { Dummy variable which is one if the firm is } \\
\text { run by a household }\end{array}$ \\
\hline Single owner & $\begin{array}{l}\text { Dummy variable which is one if the firm has } \\
\text { a single owner }\end{array}$ \\
\hline \multicolumn{2}{|c|}{ Owner/manager characteristics } \\
\hline
\end{tabular}




\begin{tabular}{|c|c|}
\hline Age & $\begin{array}{c}\text { Logarithms of the age of owner or manager in } \\
\text { years }\end{array}$ \\
\hline Gender & $\begin{array}{c}\text { Gender of owner or manager, which is one for } \\
\text { male. }\end{array}$ \\
\hline Primary education & $\begin{array}{c}\text { Dummy variable if firm owner or manager's } \\
\text { general education is primary education or } \\
\text { below. }\end{array}$ \\
\hline $\begin{array}{c}\text { Professional } \\
\text { education }\end{array}$ & $\begin{array}{c}\text { Dummy variable if firm owner or manager's } \\
\text { professional education is vocational college } \\
\text { or above. }\end{array}$ \\
\hline \multicolumn{2}{|c|}{ Environment characteristics } \\
\hline $\begin{array}{c}\text { Increasing } \\
\text { competition }\end{array}$ & $\begin{array}{c}\text { Dummy variable which is one if firms face } \\
\text { increasing competition }\end{array}$ \\
\hline
\end{tabular}

In the second regression, we use labor productivity growth as dependent variable. Labor productivity is defined as average revenue per full-time regular labor. Labor productivity growth is measured as the first difference of the logarithms of labor productivity in 2014 (reported in the 2015 survey) and 2012 (reported in the 2013 survey). Since the firms were not totally the same across surveys, we keep only firms surveyed in both years. There are 2,102 such firms and after removing missing data, we end up with 2,075 firms for analysis. For the sake of comparison and robustness check, we rerun the first regression with 2,075 firms as in the second regression. The independent variables are the same as the first regression.

The above regressions can be estimated by ordinary least squares. However, one issue with this kind of studies is the potential endogeneity between bribery behavior and firm performance. Firm performance may have a significant impact on bribery behavior as well. For example, Clarke and $\mathrm{Xu}$ (2004) analyzed firm-level data from 21 transition economies in Eastern Europe and Central Asia and showed that firm profit influences bribery activity. Svensson (2003) proved, based on the analysis of firms in Uganda, that the higher a firm's profit, the more the firm would pay bribe. On the contrary, Bai et al. (2019) argued that firm growth could reduce bribery since it increases the firm size and thus refusal power. If corrupt officials request high bribe (as a percentage of revenue), larger firms can move to other locations in the context of regional competition to attract businesses. Their theoretical argument is backed by the empirical analysis of firm data in the period of 2006-2010 in Vietnam. To deal with the issue of endogeneity, we follow the traditional approach by using instrumental variable. Particularly, we instrument a firm bribery dummy with the average bribery probability in all provinces other than the province where the firm is located. As the provinces are under the same legal and political system, it is likely that firm bribery is correlated with the average of other provinces. Also, bribery in other provinces is unlikely to correlate with the firm's performance. The model is, thus, estimated by instrumental regression with two-stage least squares.

To answer the second question, we rely on one-way Analysis of Variance technique (ANOVA), which informs us if there are differences in firm performance among groups of firms with different bribery purposes. Analysis of variance between revenue growth and purposes of bribery is conducted with 1,137 bribing firms. For labor productivity growth and purposes of bribery, 898 bribing firms are investigated.

\section{Results and Discussion}

\subsection{The Status of Bribery in Vietnamese Small and Medium Firms}

We first examine the bribery status among Vietnamese small and medium firms. As mentioned, Vietnam has a relatively high perception of corruption (Campbell \& Thomas, 2019). Consistent with the perception, we find bribery relatively widespread among small and medium firms in Vietnam. Out of 2,637 firms surveyed in 2015, 1,137 firms (43.12\%) have stated that they bribed in the year of 2014. Firms bribed for various purposes, such as for getting licenses, dealing with tax collectors, etc.

Table 2: Purposes of bribery by small and medium firms in Vietnam

\begin{tabular}{|c|c|c|}
\hline Purpose & Number of Firms & Proportion (\%) \\
\hline $\begin{array}{c}\text { To get connected to } \\
\text { public services }\end{array}$ & 216 & 19.00 \\
\hline $\begin{array}{c}\text { To get licenses and } \\
\text { permits }\end{array}$ & 63 & 5.54 \\
\hline $\begin{array}{c}\text { To deal with tax and tax } \\
\text { collectors }\end{array}$ & 278 & 24.45 \\
\hline $\begin{array}{c}\text { To gain government } \\
\text { contracts }\end{array}$ & 48 & 10.20 \\
\hline To deal with customs & 416 & 4.22 \\
\hline Other reasons & 1,137 & 36.59 \\
\hline Total & & 100 \\
\hline
\end{tabular}

Table 2 presents responses from firms as for why they bribed in 2014. The table tells us that 19 percent of firms said they bribed to get connected to public services; 5.54 percent of firms bribed to get licenses and permits from government officials. Firms also used bribery to gain some advantages in obtaining government contracts $(10.2 \%)$ or to deal with customs officials (4.22\%) and tax officials $(24.45 \%)$. About 37 percent of firms bribed for other purposes. For firms that engage in bribery, they may not bribe once but do it several times. 
Table 3 reports the number of times that firms gave bribes for whatever purposes from our data. As we can see, many firms paid bribes 2-5 times per year $(67.81 \%$ of bribing firms). 12.93 percent of firms paid bribes 6-10 times per year. 4.31 percent of firms reported that it paid bribes more than ten times a year. Only 14.95 percent of bribing firms bribed once a year.

Table 3: Number of times bribing firms paid bribes per year

\begin{tabular}{|c|c|c|}
\hline Number of times & No of Firms & Proportion (\%) \\
\hline 1 & 170 & 14.95 \\
\hline $2-5$ & 771 & 67.81 \\
\hline $6-10$ & 147 & 12.93 \\
\hline More than 10 & 49 & 4.31 \\
\hline Total & 1,137 & 100 \\
\hline
\end{tabular}

The above tables illustrate that paying bribes was relatively popular among Vietnamese small and medium firms. Firms bribed for various reasons, often to get things done, or to gain certain privileges. And they may pay bribes several times a year.

\subsection{Descriptive Statistics}

Table 4 and Table 5 present the statistics of the variables. Table 4 shows descriptive statistics for continuous variables. The t-test is used to test the mean-difference between bribing and non-bribing firms. As shown in the table, the mean of the revenue growth of bribing firms is higher than that of non-bribing firms but the difference is not statistically significant. Bribing firms appear to have significantly larger size than non-bribing firms. Bribing firms also seem to be newer than non-bribing ones. The average firm age of bribing firms is 13.4 years, compared to 17.1 years of non-bribing firms. The average age of bribing firm owners or managers is significantly lower as well.

Table 5 reports the descriptive characteristics of the dummy variables. As mentioned, 43.12 percent of firms in our data paid bribes in 2014. The statistics suggest that household firms are less likely to engage in bribery behaviors. About 38 percent of bribing firms are household firms while the ratio of household firms in non-bribing firms is 81.47 percent. Also, nearly 95 percent of nonbribing firms are run by a single owner, compared with 75.29 percent of bribing firms. There is a difference in gender between the groups as well. Higher proportion of firms managed by the male in non-bribing firms than in bribing firms. Owners/managers of bribing firms seem to have higher general and professional education. Bribing firms also have lower ratio of their owners or managers having only primary general education. Meanwhile, the proportion of owners/managers in bribing firms having professional education is higher. The differences in the above characteristics might induce differences in firm performance.

Table 4: Descriptive statistics of continuous variables

\begin{tabular}{|c|c|c|c|c|}
\hline \multirow{2}{*}{ Variable } & \multicolumn{2}{|c|}{ Bribing firms } & \multicolumn{2}{c|}{ Non-bribing firms } \\
\cline { 2 - 5 } & Mean & $\begin{array}{c}\text { Standard } \\
\text { Dev }\end{array}$ & Mean & $\begin{array}{c}\text { Standard } \\
\text { Dev }\end{array}$ \\
\hline $\begin{array}{c}\text { Revenue } \\
\text { growth }\end{array}$ & 0.047 & 0.26 & 0.035 & 0.21 \\
\hline $\begin{array}{c}\text { Labor } \\
\text { productivity } \\
\text { growth }\end{array}$ & 0.14 & 0.03 & 0.12 & 0.02 \\
\hline Total assets & $14.99^{* * *}$ & 1.47 & $13.27 * * *$ & 1.63 \\
\hline Firm age & $2.38^{* * *}$ & 0.69 & $2.63^{* * * *}$ & 0.71 \\
\hline $\begin{array}{c}\text { Age of owner } \\
\text { or manager }\end{array}$ & $3.74 * * *$ & 0.26 & $3.82^{* * *}$ & 0.24 \\
\hline
\end{tabular}

***: One percent statistically significant level.

Table 5: Descriptive statistics of dummy variables

\begin{tabular}{|c|c|c|}
\hline \multirow{2}{*}{ Variable } & \multicolumn{2}{|c|}{ Proportion (\%) } \\
\cline { 2 - 3 } & Bribery firms & $\begin{array}{c}\text { Non-bribery } \\
\text { firms }\end{array}$ \\
\hline Bribery & 43.12 & 56.88 \\
\hline Household firm & $38.25 * * *$ & $81.47 * * *$ \\
\hline $\begin{array}{c}\text { Gender of owner/manager } \\
\text { (male }=1 \text { ) }\end{array}$ & $54.18^{* * *}$ & $62.67 * * *$ \\
\hline Single owner & $75.29 * * *$ & $94.60 * * *$ \\
\hline Primary education & $3.43 * * *$ & $8.87 * * *$ \\
\hline Professional education & $42.39 * * *$ & $15.33 * * *$ \\
\hline Increasing competition & $60.42 * * *$ & $48.33 * * *$ \\
\hline
\end{tabular}

***: One percent statistically significant level.

\subsection{Empirical Results and Discussion}

Table 6 presents results of the instrumental regressions. The columns I and II are the results of the first and the second regressions respectively. Meanwhile, column III reports the results of the first regression, rerun with 2,075 observations. Consistent with the "sand the wheels" literature, our results show that bribery is negatively correlated with firm performance. The finding is significant across three regressions.

The first regression shows that bribing firms tend to have lower revenue growth by 0.12 points. Firm revenue growth is also influenced by firm size as measured by asset value. Larger firms are more likely to enjoy higher revenue growth. It is interesting that older firms seem to grow slower than newer firms. Perhaps, newer firms might be 
more dynamic, or they are more likely to have newer, more advanced technologies. Similarly, firm revenue growth appears to be affected by the age of firm owners or managers. Revenue tends to grow faster in firms with younger leaders. Firms with single owner may also grow slower though the result is significant only at 10 percent.

Our results remain relatively stable when we run the regression with lesser observations $(2,075$ firms instead of 2,627 firms - Column III). The coefficients are roughly similar between column I and column III, except that the effects of firm age and single owner dummy on revenue growth are no longer significant. Other variables do not seem to affect revenue growth as expected. We expect household firms, due to their ownership and governance structure, to exhibit different revenue growth patterns. However, we do not find any significant evidence. Similarly, the education of firm owners/managers does not show significant effects on revenue growth. Either, firm revenue growth does not seem to be influenced by increasingly competitive environment.

Table 6: Results of Instrumental regressions

\begin{tabular}{|c|c|c|c|}
\hline \multirow{2}{*}{ Variable } & \multicolumn{2}{|c|}{ Revenue Growth } & \multirow{2}{*}{$\begin{array}{c}\begin{array}{c}\text { Labor } \\
\text { Productivity } \\
\text { Growth }\end{array} \\
\text { II } \\
\end{array}$} \\
\hline & I & III & \\
\hline Bribery & $-0.12 * * *$ & $-0.11 * * *$ & $-0.65^{* * *}$ \\
\hline Total assets & $0.02 * * *$ & $0.02 * * *$ & $0.11 * * *$ \\
\hline Firm age & $-0.02 * * *$ & -0.01 & $-0.09 * * *$ \\
\hline Household firm & -0.03 & -0.03 & $-0.16^{* * *}$ \\
\hline Single owner & $-0.03 *$ & -0.01 & $-0,04$ \\
\hline $\begin{array}{c}\text { Age of } \\
\text { owner/manager }\end{array}$ & $-0.05 * * *$ & $-0.06 * * *$ & -0.009 \\
\hline $\begin{array}{c}\text { Gender of } \\
\text { owner/manager }\end{array}$ & -0.005 & -0.01 & -0.06 \\
\hline Primary education & -0.006 & -0.02 & -0.03 \\
\hline $\begin{array}{l}\text { Professional } \\
\text { education }\end{array}$ & -0.007 & -0.003 & -0.03 \\
\hline $\begin{array}{l}\text { Increasing } \\
\text { competition }\end{array}$ & 0.006 & 0.007 & $0.11 * *$ \\
\hline Constant & 0.13 & 0.15 & -0.77 \\
\hline Number of firms & 2,637 & 2,075 & 2,075 \\
\hline
\end{tabular}

The result of the second regression confirms the effect of bribery on firm performance as in the first regression. It shows that bribing firms tend to have lower labor productivity growth, indicating the existence of the sandthe-wheel effect. Moreover, labor productivity is likely to grow faster in larger firms. Probably, larger firms often invest more on capital goods and innovations. Again, older firms appear to have significantly lower labor productivity growth. However, in the second regression, we see some different findings. First, labor productivity growth tends to be lower in household firms as expected. Second, singerowner firms are unlikely to have lower productivity growth as the result is not statistically significant. Third, it is interesting that increasing competition is positively related to productivity growth. This may imply that in stronger competition environments, firms may have to focus more on labor productivity growth. Other variables appear insignificant in influencing labor productivity growth.

Thus, the findings are relatively consistent across regressions. Our findings reject the grease-the-wheels hypothesis that bribery boosts firm performance since it helps to get things done, especially in relatively corrupt countries like Vietnam.

To examine if the effects of bribery on firm performance depend on the purposes of bribery, we then conduct the Analysis of Variance (ANOVA). Table 7 show the analysis of variance with revenue growth as the dependent variable. We use category "others" as the base category. The results show that bribery might affect firm revenue growth differently with different bribing purposes. The betweengroup effect is significantly different from zero. Among bribing firms, those bribed to get licenses or permits or to deal with tax collectors tend to enjoy higher revenue growth. That is, some bribery behaviors may be more helpful to firm revenue growth than the others though bribery is, in general, harmful to firm performance.

Table 7: Analysis of Variance - Effects of bribery purposes on Firm Revenue Growth

\begin{tabular}{|c|c|c|c|c|c|}
\hline Source & SS & Df & MS & $\begin{array}{c}\text { F- } \\
\text { statistics }\end{array}$ & Prob>F \\
\hline $\begin{array}{c}\text { Between } \\
\text { groups }\end{array}$ & 0.78 & 5 & 0.155 & 2.27 & 0.045 \\
\hline $\begin{array}{c}\text { Within } \\
\text { groups }\end{array}$ & 77.22 & 1131 & 0.068 & & \\
\hline Total & 77.99 & 1136 & 0.068 & & \\
\hline
\end{tabular}

Table 8: Analysis of Variance - Effects of bribery purposes on Labor Productivity Growth

\begin{tabular}{|c|c|c|c|c|c|}
\hline Source & SS & Df & MS & $\begin{array}{c}\text { F- } \\
\text { statistics }\end{array}$ & Prob>F \\
\hline $\begin{array}{c}\text { Between } \\
\text { groups }\end{array}$ & 4.74 & 5 & 0.95 & 1.52 & 0.18 \\
\hline $\begin{array}{c}\text { Within } \\
\text { groups }\end{array}$ & 556.41 & 890 & 0.63 & & \\
\hline Total & 561.15 & 895 & 0.63 & & \\
\hline
\end{tabular}

Table 8 informs the finding from the analysis of variance with labor productivity growth as the dependent 
variable. It shows that between-group effect is insignificant. That implies that no purposes of bribery are better than others in terms of helping labor productivity growth. It may be true that bribery can help some firms overcome some difficulties in getting things done, such as when they attempt to get licenses or permits or when they work with tax collectors and customs officials. However, the net effect of bribery is negative. It hurts firm revenue growth and labor productivity growth. While there may be differences in the effects of various bribery purpose on firm performance, the difference may not be robust and may only valid in the short-term. Our results, therefore, support the "sand the wheels" hypothesis that bribery impedes firm performance, even in a relatively corrupt business environment.

\section{Conclusions}

In this paper, we attempt to revisit the hypothesis that bribery hurts firm performance. The literature on the relationship between bribery and firm performance has been still inconclusive about whether bribery helps or hurts firms, especially in countries with relatively high degrees of corruption. Using micro-data from Vietnamese small and medium enterprise surveys, we find new evidence that supports the sand-the-wheels hypothesis. Our findings confirm that bribery significantly hinders firm revenue growth and labor productivity growth. While the effects of bribery on firm performance may vary across bribery purposes, the difference may not be robust or significant. Overall, the net effect is still negative. Our findings reject the hypothesis that, in countries with bad business environment or relatively high corruption, bribery boosts firm performance by getting things done.

\section{References}

ACCA (2019). Combating bribery in the SME sector, ACCA report. Retrieved February 01, 2020, from https://www.accaglobal.com/content/dam/ACCA_Global/prof essionalinsights/CombatingBribery2019/JasonPiper.CombatingBriber ySMEsector.pdf

Arvis, J.-F. (2003). Fighting corruption in East Asia: Solutions from the private sector (No. 26887, p. 1). Retrieved February 01, 2020, from The World Bank website: http://documents.worldbank.org/curated/en/845161468770741 943/Fighting-corruption-in-East-Asia-solutions-from-theprivate-sector

Asiedu, E., \& Freeman, J. (2009). The Effect of Corruption on Investment Growth: Evidence from Firms in Latin America, Sub-Saharan Africa, and Transition Countries. Review of
Development Economics, 13(2), 200-214. https://doi.org/10/d5sb8p

Bai, J., Jayachandran, S., Malesky, E. J., \& Olken, B. A. (2019). Firm Growth and Corruption: Empirical Evidence from Vietnam. The Economic Journal, 129(618), 651-677. https://doi.org/10/gfzt7b.

Campbell, L., \& Thomas, A. (2019). People's Experiences of Corruption: Implications for Business in South-East Asia, Transparency International 2019 report. Retrieved February 01, 2020, from http://files.transparency.org/content/download/2411/14666/file /2019_Report_\%20ExperiencesCorruptionImplicationsBusine ssSouth-EastAsia_English.pdf

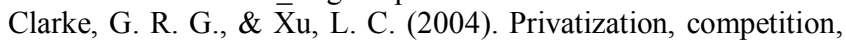
and corruption: How characteristics of bribe takers and payers affect bribes to utilities. Journal of Public Economics, 88(9), 2067-2097. https://doi.org/10/bpf9d9

Dal Bó, E., \& Rossi, M. A. (2007). Corruption and inefficiency: Theory and evidence from electric utilities. Journal of Public Economics, 91(5), 939-962. https://doi.org/10/b23bjm

De Rosa, D., Nishaal, G., \& Holger, G. (2015). Corruption and Productivity: Firm-level Evidence. Journal of Economics and Statistics (Jahrbuecher Fuer Nationaloekonomie Und Statistik), 235(2), 115-138.

Dreher, A., \& Gassebner, M. (2013). Greasing the wheels? The impact of regulations and corruption on firm entry. Public Choice, 155(3), 413-432. https://doi.org/10/cw54zp

Dutta, N., \& Sobel, R. (2016). Does corruption ever help entrepreneurship? Small Business Economics, 47(1), 179-199. https://doi.org/10/ggjpc8

Essel, B. K. C., Adams, F., \& Amankwah, K. (2019). Effect of entrepreneur, firm, and institutional characteristics on smallscale firm performance in Ghana. Journal of Global Entrepreneurship Research, 9(1), 55. https://doi.org/10/ggjqrd

Fisman, R. (2001). Estimating the Value of Political Connections. American Economic Review, 91(4), 1095-1102. https://doi.org/10/db6fqk

Fisman, R., \& Svensson, J. (2007). Are corruption and taxation really harmful to growth? Firm level evidence. Journal of Development Economics, 83(1), 63-75. https://doi.org/10/cnvgz8

Gauthier, B., \& Goyette, J. (2014). Taxation and corruption: Theory and firm-level evidence from Uganda. Applied Economics, 46(23), 2755-2765. https://doi.org/10/ggjp3m

Gaviria, A. (2002). Assessing the effects of corruption and crime on firm performance: Evidence from Latin America. Emerging Markets Review, 3(3), 245-268. https://doi.org/10/bqj9zm

Gundlach, E., \& Paldam, M. (2009). The transition of corruption: From poverty to honesty. Economics Letters, 103(3), 146-148. https://doi.org/10/fwbk7w

Hanoteau, K., \& Vial, V. (2014). Grease or Sand the Wheel? the Effect of Individual Bribes on the Drivers of Aggregate Productivity Growth. Journal of Indonesian Economy and Business, 29(1), 1-16. https://doi.org/10/ggjqq9.

Hellman, J., \& Schankerman, M. (2000). Intervention, Corruption and Capture: The Nexus between Enterprises and the State. Economics of Transition and Institutional Change, 8(3), 545576. https://doi.org/10/cr29dn

Hellman, J.S., Jones, G., Kaufman, D., \& Shankerman, M. (2000). 
Measuring governance, corruption and state capture: How firms and bureaucrats shape the business environment in transition economies (World Bank Policy Research Working Papers 2312). The World Bank, Washington, DC.

Kaufmann, D., \& Wei, S.-J. (1999). Does “Grease Money” Speed Up the Wheels of Commerce? (NBER Working Papers No. 7093). Retrieved from National Bureau of Economic Research, Inc website: https://EconPapers.repec.org/RePEc:nbr:nberwo:7093

Mauro, P. (1995). Corruption and Growth. The Quarterly Journal of Economics, 110(3), 681-712. https://doi.org/10/ctqs8f

Mendoza, R. U., Lim, R. A., \& Lopez, A. O. (2015). Grease or Sand in the Wheels of Commerce? Firm Level Evidence on Corruption and SMES. Journal of International Development, 27(4), 415-439. https://doi.org/10/ggjpcx

Méon, P.-G., \& Sekkat, K. (2005). Does corruption grease or sand the wheels of growth? Public Choice, 122(1), 69-97. https://doi.org/10/c2jghb

Murphy, K. M., Shleifer, A., \& Vishny, R. W. (1991). The Allocation of Talent: Implications for Growth. The Quarterly Journal of Economics, 106(2), 503-530. https://doi.org/10/fwv996

Nur-tegin, K., \& Jakee, K. (2019). Does corruption grease or sand the wheels of development? New results based on disaggregated data. The Quarterly Review of Economics and Finance. https://doi.org/10/ggh49x.

O'Toole, C. M., \& Tarp, F. (2014). Corruption and the Efficiency of Capital Investment in Developing Countries. Journal of International Development, 26(5), 567-597. https://doi.org/10/f6bpm5

Park, S. H., \& Luo, Y. (2001). Guanxi and organizational dynamics: Organizational networking in Chinese firms. Strategic Management Journal, 22(5), 455-477. https://doi.org/10.1002/smj.167

Peng, M. W., \& Luo, Y. (2000). Managerial ties and firm performance in a transition economy: The nature of a micromacro link. Academy of Management Journal, 43(3), 486501.

Radaev, V. (2004). How Trust is Established in Economic Relationships when Institutions and Individuals Are Not
Trustworthy: The Case of Russia. In J. Kornai, B. Rothstein, \& S. Rose-Ackerman (Eds.), Creating Social Trust in PostSocialist Transition (pp. 91-110). https://doi.org/10.1057/9781403980663_6

Romer, P. (1994). New goods, old theory, and the welfare costs of trade restrictions. Journal of Development Economics, 43(1), 5-38. https://doi.org/10/cqs96w

Svensson, J. (2003). Who Must Pay Bribes and How Much? Evidence from a Cross Section of Firms. The Quarterly Journal of Economics, 118(1), 207-230. https://doi.org/10/b2cp44

Treisman, D. (2000). The causes of corruption: A cross-national study. Journal of Public Economics, 76(3), 399-457. https://doi.org/10/dxb6fc

UNIDO \& UNODC (2007) Corruption Prevention to Foster Small and Medium size Enterprise Development. Vienna International Centre, Vienna, Austria. Retrieved from https://www.unodc.org/documents/corruption/Publications/20 12/Corruption_prevention_to_foster_small_and_medium_size _enterprise_development_Vol_2.pdf

Vial, V., \& Hañoteau, J. (2010). Corruption, Manufacturing Plant Growth, and the Asian Paradox: Indonesian Evidence. World Development, 38(5), 693-705. https://doi.org/10/ckzdqk

Wu, X. (2009). Determinants of Bribery in Asian Firms: Evidence from the World Business Environment Survey. Journal of Business Ethics, 87(1), 75-88. https://doi.org/10.1007/s10551008-9871-4

Yin, H., \& Zhang, R. (2019). The Nature of Controlling Shareholders, Political Background and Corporate AntiCorruption Practice Disclosure. Journal of Asian Finance, Economics and Business, 6(1), 47-58. http://doi.org/10.13106/jafeb.2019.vol6.no1.47

Young, M. N., Ahlstrom, D., Bruton, G. D., \& Rubanik, Y. (2011). What do firms from transition economies want from their strategic alliance partners? Business Horizons, 54(2), 163174. https://doi.org/10/b6mn37.

Zhou, J. Q., \& Peng, M. W. (2012). Does bribery help or hurt firm growth around the world? Asia Pacific Journal of Management, 29(4), 907-921. DOI: 10.1007/s10490-0119274-4 